\title{
NUMERICAL SIMULATION OF A CANTILEVER FAILURE WITH THE EFFECT OF SLUMP BLOCKS FOR COHESIVE RIVERBANKS
}

\author{
Supapap PATSINGHASANEE ${ }^{1}$, Ichiro KIMURA ${ }^{2}$ and Yasuyuki SHIMIZU 3 \\ ${ }^{1}$ Member of JSCE, Ph.D. candidate, Division of Field Engineering for Environment, Hokkaido University \\ (Kita 13, Nishi 8, Kitu-ku, Sapporo 060-8628, Japan) \\ ${ }^{2}$ Member of JSCE, Associate Prof., Division of Field Engineering for Environment, Hokkaido University \\ (Kita 13, Nishi 8, Kitu-ku, Sapporo 060-8628, Japan) \\ ${ }^{3}$ Member of JSCE, Professor, Division of Field Engineering for Environment, Hokkaido University \\ (Kita 13, Nishi 8, Kitu-ku, Sapporo 060-8628, Japan)
}

\begin{abstract}
The consideration of slump blocks in the coupling fluvial erosion and cantilever failure model is the recent advancement toward dealing the phenomena of riverbank failures. In this study, we developed a numerical modeling of a cantilever failure that uses a triple-grid approach to simulate the behavior of a cantilever within the framework of fluvial erosion, the cantilever's subsequent failure, slump block effect and bedload sedimentation. Two cases of cohesive materials with the different percentages of silt-clay content were simulated under the similar hydraulic conditions with and without slump block consideration. The simulated results in terms of the fluvial erosion and cantilever failure showed significantly difference due to inclusion of slump block consideration. The present numerical model with slump block consideration satisfactorily reproduced the riverbank failure phenomena and showed good agreement with the experimental results in terms of the spatial-averaged bank width along the riverbanks.
\end{abstract}

Key Words : cantilever failure, fluvial erosion, slump block, cohesive riverbank, numerical modeling

\section{INTRODUCTION}

A cantilever failure among the various bank failures is very common phenomena observed in the natural rivers and it affects a wide range of physical, ecological and socioeconomic issues in the fluvial environment ${ }^{1)}$. However, the reproduction and simulation of a cantilever failure mechanism using a numerical model are a challenging task for understanding bank failure phenomenon before any new construction works such as ripraps, gabions, mattresses and pipe line crossings, etc.

For previous studies, researchers have been unable to analyze a cantilever failure and have focused mainly on simple bank failures such as rotational slip failure, toppling failure and mass wasting failure ${ }^{2), 3}$. Only a few studies have applied stability analyses based on the safety factor of the portion with cantilever failure, upon which three types of possible cantilever failure mechanisms have been defined: shear-type, beam-type and tensile-type failures ${ }^{4), 5}$. After cantilever failure, the overhanging blocks crumble down in a shape like slump blocks and cover the bank-toe. It is thought that the fluvial erosion rate decreased because of the failure of slump blocks ${ }^{6}$. The simplified process of slump blocks was developed in a two-dimensional depth-averaged model for reproducing meandering evolution process in small-scale experiments ${ }^{6)}$ and natural rivers ${ }^{7}$. The previous studies ${ }^{6,7)}$ employed the simple bank failure concept with the slump block effect based on submerged angle of repose. In such model, when the riverbed near the bank erodes and the cross sectional gradient of the bank slope becomes steeper than the angle of repose, the slump block is assumed to be generated. After that, the slump block is deposited at the bank-toe and the bank is then armored. However, the simple bank failure concept cannot reproduce the complex mechanisms of a cantilever failure ${ }^{8)}$. Therefore, the previous slump block concepts cannot apply for simulating cantilever failure phenomena. 
For numerical model, a coupled model of fluvial erosion and mass wasting was developed to reproduce fluvial erosion processes in a bank-toe, degradation in a channel bed and destabilization of an upper bank ${ }^{9)}$. In a cantilever failure model, the numerical model was developed to identify the overhanging block dimensions and cohesive force, which are highly significant for a cantilever stability ${ }^{10)}$. Additionally, the overhanging block model was applied for computing the safety factor by limited equilibrium methods, defined as the ratio between stabilizing and destabilizing forces ${ }^{11)}$. However, these previous studies have limitations in the coupling fluvial erosion and cantilever failure.

A coupling fluvial erosion and cantilever failure model was recently proposed to simulate the subsequent failure of the overhanging block ${ }^{8)}$. The limitation of the recent modeling ${ }^{8}$ was in the quantification of the fluvial erosion rate $(\varepsilon)$ derived from the erodibility coefficient $\left(k_{d}\right)$ because the determination of $k_{d}$ still remains complex, depended on several factors (i.e., water content, cohesive force, and silt-clay content) ${ }^{12)}$. Thus, for the determination of $\varepsilon$, the relationship of $k_{d}$ and $\tau_{b c}$ are needed to be measured locally. However, this previous study has the another limitation in the coupling fluvial erosion and cantilever failure with the slump block effect and simulations coupling fluvial erosion, cantilever failure and slump block consideration therefore need to be conducted.

To deal with the limitations in the previous numerical models of the processes for a cantilever failure, a novel coupled numerical model by considering the effects of fluvial erosion, cantilever failure, slump block and bedload sedimentation was developed to simulate the cantilever failure mechanism in the experimental scale.

\section{METHODOLOGY}

This section provides an overview of a description of the numerical model.

A cantilever failure model was developed by implementing a triple-grid approach, consisting of a coarse one-dimensional (1D) grid for the flow field in the lateral direction, a fine 1D grid for sediment transport and bed deformation in lateral direction and a 2D grid for cantilever failure and slump block in the vertical and lateral directions (Fig. 1). During the initial stage of the computation (Fig. 2), the model reproduces fluvial erosion at the lower part around the wetted perimeter of the bank, which is shown by the dash-dotted line in zone I. Next, the tension crack in zone II and the cantilever failure in zone III (the dashed vertical line along the bank) are captured. For beam-type failure, the failure block is turned into the channel at $90^{\circ}$ in the anti-clockwise direction and dropped at riverbed (see Fig. 3(a)). The pivot of the rotation is located at the lowest edge of the failure block along the failure plane. On the other hand, the overhanging failure block directly comes to rest at the intermediate drop point for shear-type failure (Fig. 3(b)). The slump block failure and decomposition are then developed at the foot of the bank slope in zone IV (Fig. 2). This approach involves applying the four submodels-fluvial erosion, cantilever failure, slump block and bedload sedimentation - at each of a series of discrete timesteps. A logic diagram of the computational sequence used for the coupled mechanism is illustrated in Fig. 4.

\section{(1) The fluvial erosion rate}

Fluvial bank erosion rate is quantified using an excess shear stress formula around the wetted perimeter, including bottom, lateral and top sides of the cohesive bank (see the blue arrows in Fig.2) as given below ${ }^{13)}$.

$$
\varepsilon=k_{d}\left(\tau_{b 0}-\tau_{b c}\right)^{a}
$$

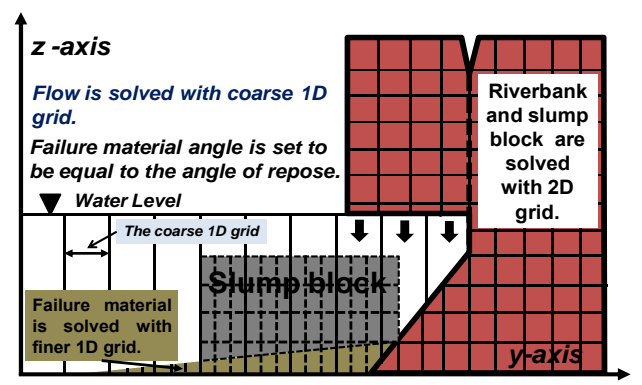

Fig.1 The framework of triple-grid approach of cantilever failure model with the slump block consideration.

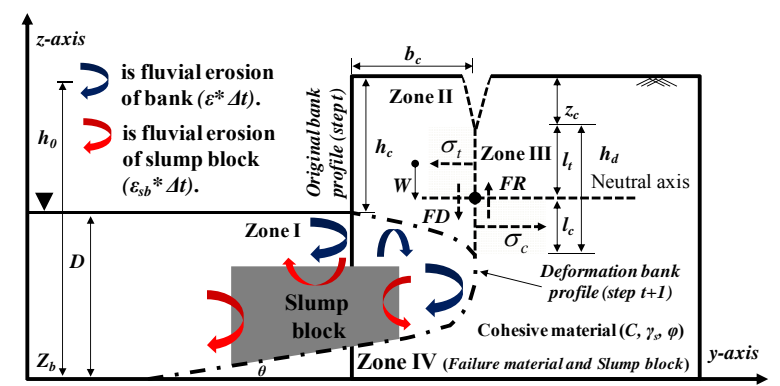

Fig.2 The overhanging geometry and forces exerted on the incipient failure block. $h_{0}$ is initial bank height $[\mathrm{m}], h_{c}$ is overhanging block height $[\mathrm{m}], b_{c}$ is overhanging block width $[\mathrm{m}], z_{c}$ is tension crack depth $[\mathrm{m}], l_{t}$ and $l_{c}$ are tensile and compressive zone length [m], $D$ is water depth $[\mathrm{m}], Z_{b}$ is bed elevation $[\mathrm{m}], W$ is overhanging block weight $[\mathrm{kN}], C$ is the cohesive force [Pa], $\sigma_{t}$ and $\sigma_{c}$ are tensile and compressive stress $\left[\mathrm{kN} / \mathrm{m}^{2}\right], F R$ and $F D$ are resultant resisting and driving forces acting on the overhanging failure block, $\theta$ is angle of repose, $\phi$ is friction angle, $\gamma_{s}$ is unit weight of soil $\left[\mathrm{kN} / \mathrm{m}^{3}\right], \varepsilon$ and $\varepsilon_{s b}$ are the fluvial erosion rate of the bank and slump block $[\mathrm{m} / \mathrm{s}], \Delta t$ is the timestep [s]. 
where $\varepsilon$ is the fluvial erosion rate of the bank $(\mathrm{m} / \mathrm{s})$, $k_{d}$ is the erodibility coefficient $\left(\mathrm{m}^{3} /(\mathrm{N} \mathrm{s})\right), \tau_{b 0}$ is the actual shear stress applied by the flow $(\mathrm{Pa}), \tau_{b c}$ is the critical shear stress $(\mathrm{Pa})$ and $a$ (dimensionless) is the exponent generally assumed to equal 1.0. In Eq.(1), the positive value of excess shear stress is only considered for fluvial erosion estimation. Although Eq.(1) appears simple, it includes a complicated parameter $\left(k_{d}\right)$. The value of $k_{d}$ is tuned through the comparison with the results of the preliminary experimental studies.

The flow field is calculated using a uniform flow model on a coarse lateral 1D grid cell. In order to avoid the small grid cell width at vicinity area of the bank, the grid cell division starts from the edge of the bank instead the left side of the computational domain. Therefore, Eq.(2) can considers the complicated shape of the erosion near the bank by evaluating the hydraulic radius in a coarse lateral grid cell.

$$
u_{j}=\frac{1}{n} R_{j}^{2 / 3} i^{1 / 2}
$$

where $u_{j}$ is the velocity in each calculated cell, $n$ is the Manning roughness parameter along the channel (0.011) calculated using the Manning-Strickler equation $\left(k_{s}^{1 / 6} / 7.66 g^{1 / 2}\right)$ in which $g$ is the gravitational acceleration $\left(9.81 \mathrm{~m} / \mathrm{s}^{2}\right)$ and $k_{s}$ is the roughness height defined as $1-3 d_{50}, R_{j}$ is the hydraulic radius in each calculated cell, $i$ is the bed slope and $j$ is the lateral calculated cell number.

The actual shear stress is determined by the function of hydraulic radius and channel slope in each calculated cell as shown in Eq.(3). The empirical equation of the critical shear stress for the function of the percentage of silt-clay content (SC) is employed as expressed in Eq.(4) ${ }^{12)}$.

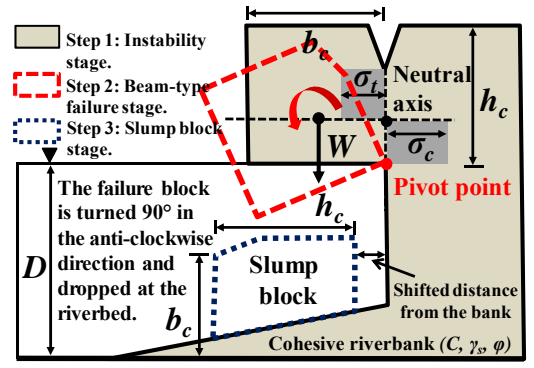

(a) Beam-type failure.

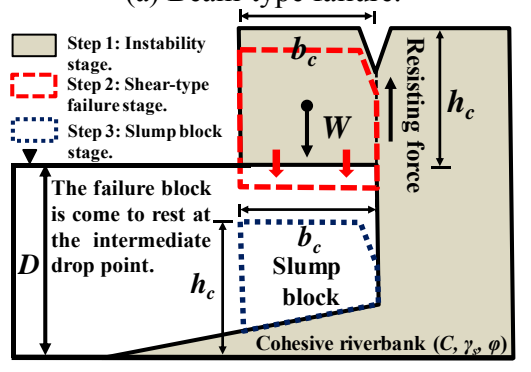

(b) Shear-type failure.

Fig.3 Slump block locations and dimensions.

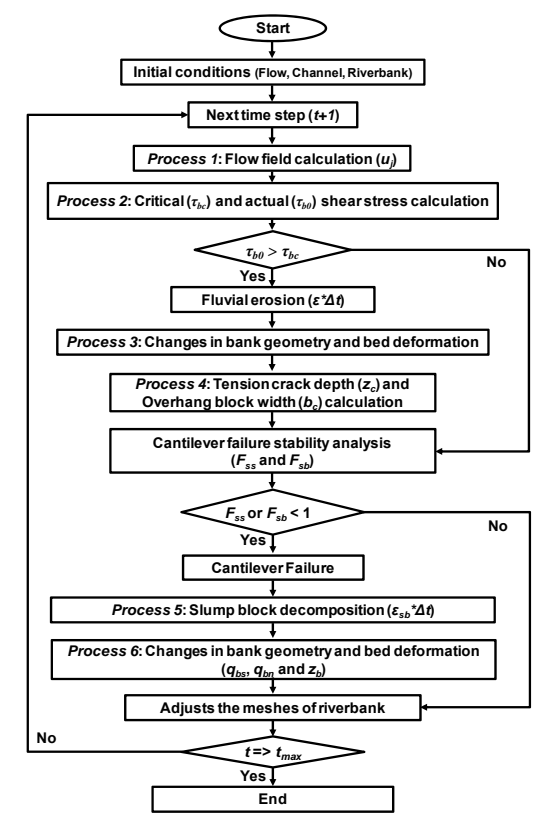

Fig.4 The logic diagram of the computational sequence.

$$
\begin{gathered}
\tau_{b 0}=\rho g R_{j} i \\
\tau_{b c}=0.1+0.1779(S C)+0.0028\left(S C^{2}\right) \\
-2.34 E^{-5}\left(S C^{3}\right)
\end{gathered}
$$

where $\rho$ is the density of water $\left(1,000 \mathrm{~kg} / \mathrm{m}^{3}\right)$.

To characterize the fluvial erosion rate eroded around the wetted perimeter of the bank, the fluvial erosion rate (Eq.(1)) is evaluated in each timestep by the function of the $k_{d}, \tau_{b 0}$ and $\tau_{b c}$ to erode the bank in the vertical and lateral directions. For actual shear stress, this procedure is a simple method to evaluate the near-bank shear stress by neglecting the lateral shear stress. This procedure is an idealization of the fluvial erosion rate estimation, but was used simply to simulate the coupled numerical model of cantilever failure phenomena.

\section{(2) The cantilever failure}

For cantilever failure, we defined the failure blocks by considering the safety factor for two types of failure i.e., the shear-type ${ }^{4)}$ and beam-type ${ }^{10)}$ failure. A cantilever failure will occur if any of the blocks have a safety factor of less than one.

Shear-type failure is expected when the shear stress along the vertical plane from the overhanging block weight $(F D)$ exceeds the cohesive force $(F R)$, as shown in Fig. 2 and 3(b). The safety factor of shear-type failure $\left(F_{s s}\right)$ is described as

$$
F_{s s}=\frac{C h_{d}}{\gamma_{s} A_{b}}
$$

where $h_{d}$ is the effective length $\left(h_{c}-z_{c}\right)(\mathrm{m})$ and $A_{b}$ is the cross-sectional area of overhanging block $\left(\mathrm{m}^{2}\right)$.

Beam-type failure is related to unstable overhanging block rotating around a neutral axis 
(Fig. 2 and 3(a)). Above the axis failure is in tension and below it, in compression. This occurs when the rotational moment of overhanging block overcomes the resistive moment of soil's strength in the tension and compression zones. The safety factor of beam-type failure $\left(F_{s b}\right)$ can be described as

$$
F_{s b}=\frac{\sigma_{c} l_{c}^{2}+\sigma_{t} l_{t}^{2}}{\gamma_{s} h_{c} b_{c}^{2}}
$$

with $h_{d}=l_{c}+l_{t}$ and $\sigma_{d} / \sigma_{t}=l_{t} / l_{c}$, where $l_{c}$ and $l_{t}$ are the overhanging length under compressive and tensile stress (m), and $\sigma_{c}$ and $\sigma_{t}$ are the compressive and tensile strength of cohesive bank $\left(\mathrm{kN} / \mathrm{m}^{2}\right)$.

The tension crack depth $\left(z_{c}\right)$ is assumed to be 0.5 of the overhanging block height $\left(h_{c}\right)$ because the variation in $z_{c} / h_{c}$ from 0.3 to 0.7 in Eq.(5) and Eq.(6) does not change the factor of safety by more than $10 \%{ }^{14)}$.

\section{(3) The mesh adaptation}

The bank profiles are deformed to accord with the fluvial erosion simulated at the end of each discrete timestep. Therefore, the undisturbed cell occupation rate $\left(\Omega_{t}\right)$ is achieved as expressed in Eq.(7) through two possible scheme (see Fig.5).

$$
\Omega_{t}=\frac{\left[V_{\text {org }}-\sum_{t=1}^{n} V_{\text {erd }}\right]}{V_{\text {org }}}
$$

where $V_{\text {org }}$ is the initial grid cell volume of a cohesive bank $\left(\mathrm{m}^{3}\right)$ and $V_{\text {erd }}$ is the simulated fluvial erosion volume in each timestep $\left(\mathrm{m}^{3}\right)$.

For the first scheme, if the accumulated fluvial erosion volume is less than the initial grid cell volume of the bank, the boundary nodes are not shifted horizontally inward through the fluvial erosion (Fig. 5(a)). For the second scheme, if the accumulated fluvial erosion volume is equal to or larger than the initial grid cell volume of the bank, the new grid cells are assigned to update the new bank profile nodes (Fig. 5(b)).

\section{(4) The slump block effect}

For slump block effect, we proposed the novel scheme in this study. The overhanging block immediately drops into riverbed and becomes to be a slump block after a cantilever failure. Therefore, slump block dimensions are assumed to be equal to the overhanging block dimensions ( $h_{c}$ and $b_{c}$ ). However, the settled dimensions of the slump block are different between shear-type and beam-type failures (see Fig. 3). The decomposition processes of the slump block are then induced by the fluvial erosion at the submerged surface of the slump block (see zone IV in Fig. 2). The erosion rate of slump block is calculated as

$$
\varepsilon_{s b}=k_{s b} * \varepsilon
$$

where $\varepsilon_{s b}$ and $\varepsilon$ are the fluvial erosion rate of the slump block and the bank $(\mathrm{m} / \mathrm{s})$ and $k_{s b}$ is the coefficient of the fluvial erosion rate (1.2) that was forcing best agreement between calculated and measured streamwise average bank width.

\section{(5) The bedload transport and bed deformation}

After fluvial erosion, the eroded materials are assumed to become non-cohesive and formed as bedload. The behavior of the bedload transport and bed deformation are calculated in the same processes with our previous study ${ }^{8}$.

\section{RESULTS AND DISCUSSION}

In this section, we express and discuss the results between the computational and experimental results. The experiments were carried out in a straight rectangular flume. The water and sediments were recirculated using a constant head tank of water placed at the upstream end of flume. Moreover, to reproduce a steady uniform flow, the discharge remained constant at $6.45 \mathrm{l} / \mathrm{s}$. The dimensions of the experimental flume was $0.8 \mathrm{~m}$ in width, $8.0 \mathrm{~m}$ in length and $0.4 \mathrm{~m}$ in height and the flume slope was set 0.001 . In the upstream region of the flume ( 0.0 to $3.0 \mathrm{~m}$ from the upstream), a wooden board was installed to avoid fluvial erosion. At the middle reach of the flume (3.0 to $5.0 \mathrm{~m}$ from the upstream), a cohesive bank was set. The cohesive bank was $0.5 \mathrm{~m}$ wide, $2.0 \mathrm{~m}$ long and 0.2 $\mathrm{m}$ high. Downstream of the cohesive bank, a second wooden board was installed. The cohesive materials were composed of sand and silt with a mean diameter $\left(d_{50}\right)$ of $0.23 \mu \mathrm{mm}$ and $28.4 \mu \mathrm{m}$, respectively. The materials were well mixed by slowly adding water. The sediment mixtures were thus initially wetted to achieve a water content (WC) between $32.2 \%$ and $39.6 \%$ for the silt-clay contents (SC) of $20 \%$ and $30 \%$. The cohesive bank properties used in the experiments are summarized in Table 1.
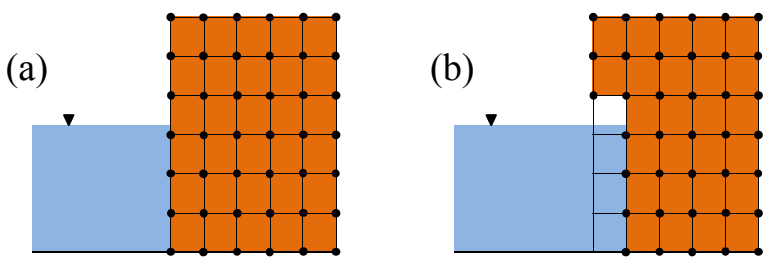

Fig.5 Illustration of the two schemes used to adopt the boundary nodes by the effect of fluvial erosion.

Table 1 Summary of the experimental conditions.

\begin{tabular}{|c|c|c|c|c|c|c|}
\hline Case & $\begin{array}{c}S C \\
(\%)\end{array}$ & $\begin{array}{c}W C \\
(\%)\end{array}$ & $\begin{array}{c}C \\
(\mathrm{kPa})\end{array}$ & $\begin{array}{c}\phi \\
\left({ }^{\circ}\right)\end{array}$ & $\begin{array}{c}\tau_{b c} \\
(\mathrm{kPa})\end{array}$ & $\begin{array}{c}k_{d} \\
\left(\mathrm{~m}^{3} /(\mathrm{N} \mathrm{s})\right)\end{array}$ \\
\hline 1 & 30 & 39.6 & 5.76 & 34.3 & 0.57 & 105.6 \\
\hline 2 & 20 & 32.2 & 6.41 & 41.3 & 0.38 & 42.8 \\
\hline
\end{tabular}


Numerical simulations for duration about 6 hours (real time) were performed under the same conditions with the experiments. In Fig. 6, the numerical and experimental results of the streamwise averaged bank width were compared with a perfect agreement line, which fell within a range of $15 \%$ error line in Case 1 and $10 \%$ error line in Case 2. The numerical results of Case 1 were about 1.2 times higher than the experimental results at the nearly equilibrium stage. Moreover, the main error of Case 2 was occurred from the fifth to seventh failures. The main reason of the overestimation is that the model has a limitation to decompose the large slump block volume.

The fluvial erosion rate in Case 1 was greater than that in Case 2 at $270 \mathrm{~s}$, as shown in Fig. 7, indicating that banks with higher silt-clay content (SC) are more susceptible to failure than those with lower SC. The observations of the present work were similar to the previous studies in term of changing silt-clay content ${ }^{1,88,12}$. Moreover, the numerical results with different $S C$ were consistent with the experimental results. Fig. 8 shows the comparison of the spatial-averaged bank width between the numerical results with and without slump block consideration, together with the experimental results. The numerical results with slump block showed good agreement with the experimental results. The results clearly showed that the cantilever failures are suppressed by the effect of slump block. On the other hand, the numerical results without slump block cannot replicate the complex mechanism of a cantilever failure. Therefore, the slump block effect on a cantilever failure model has highly significant effect for reproducing the phenomena.

Fig. 9(a) and 9(c) illustrate cross sectional views at the failure stages with a slump block, simulated using the numerical model. These figures show the occurrence of fluvial erosion at both slump block and bank in the submerged zone. This process occurred through the fluvial erosion at the slump block and undermining the bank. In present stage, the slump block was eroded in the three sides of block (left, right and top sides). During slump block decomposition, the erosion rate of the bank was less than the initial rate. On the other hand, in Fig. 9(b) and 9(d), the model without the slump block effect cannot reproduce the complicated mechanisms of a cantilever failure. Additionally, the numerical results showed the overestimated results in terms of the fluvial erosion rate.

The beam-type failure was the dominated failure mechanism in the numerical results. The numerical results are similar with the experiments, showing the beam-type failure is the dominant failure mechanism. In addition, the width of overhanging block in the numerical results were within the range of 5.7 to $6.0 \mathrm{~cm}$, while those in the experimental results were within the range of 5.7 and $14.3 \mathrm{~cm}$. Therefore, we can conclude that the simulated results were consistent with the experimental results in terms of the dimensions of overhanging blocks.

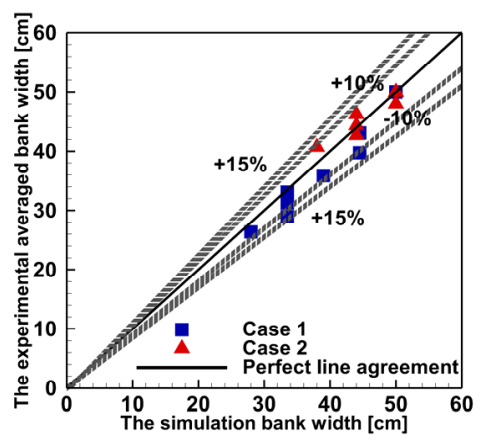

Fig.6 Comparison between numerical and experimental results in the streamwise averaged bank width.

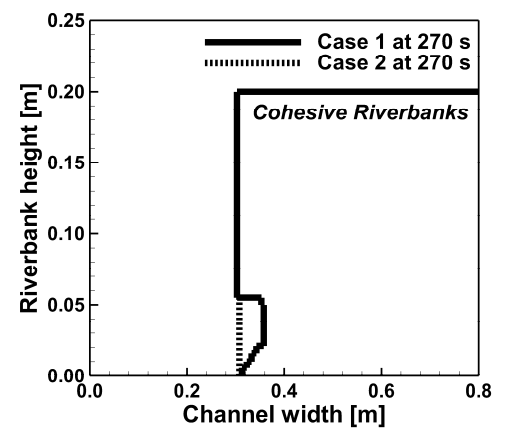

Fig.7 The riverbank geometry of the numerical results.

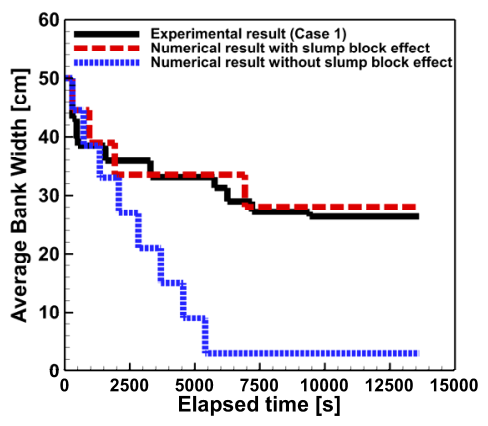

(a) Case 1 .

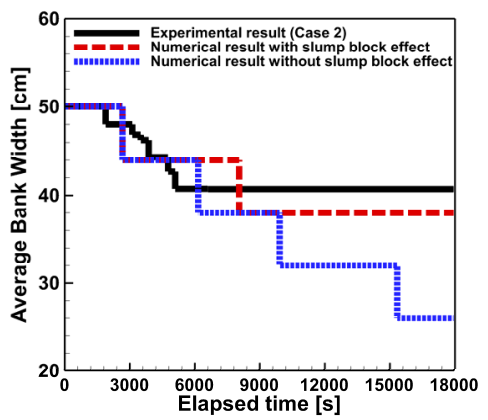

(b) Case 2.

Fig.8 The comparison of spatial-averaged bank width with and without slump block consideration, together with the experimental results. 


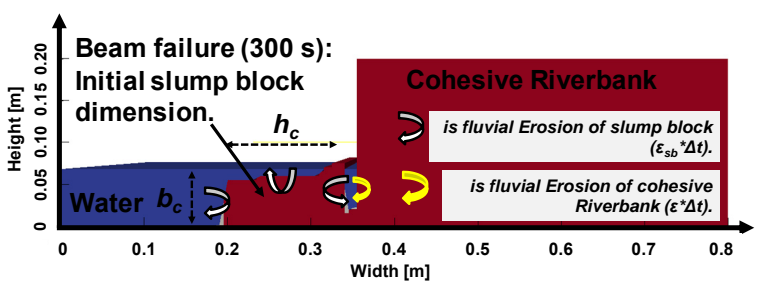

(a) The slump block on the riverbed after failure.

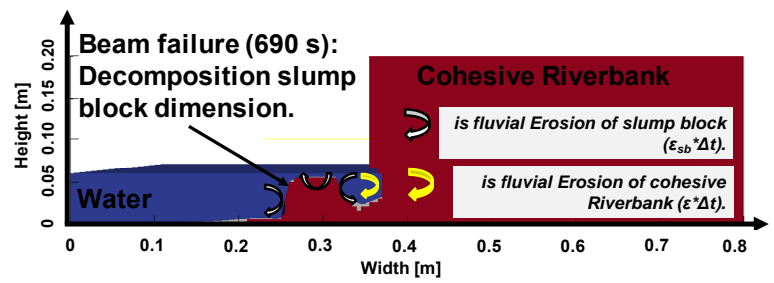

(c) The slump block erosion on the riverbed.

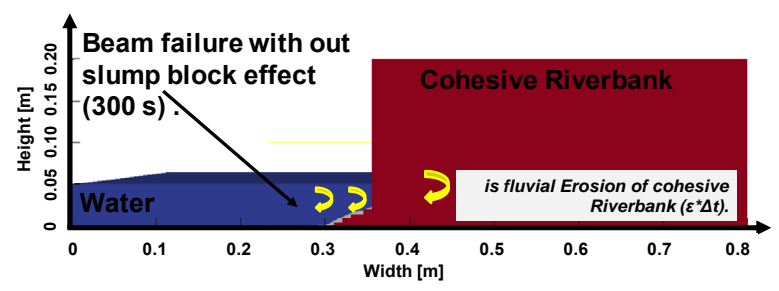

(b) No slump block on the riverbed after failure.

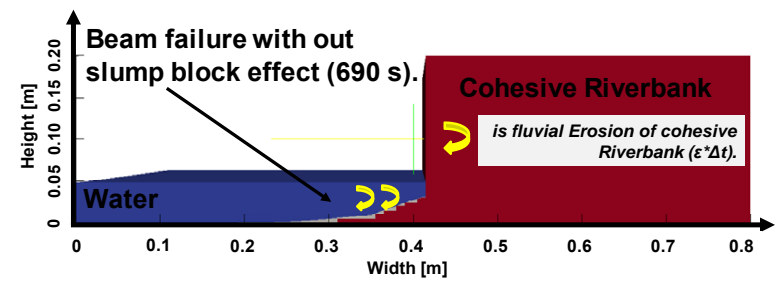

(d) No slump block erosion on the riverbed.

Fig.9 Cross-sectional views of computational results in Case 1 with slump block effect (a and c), and without slump block effect (b and d) (brown: undisturbed cohesive material, gray: non-cohesive bedload, blue: water).

As in the numerical model, the present model is a cross-sectional 2D model. Such a model is limited in its ability to simulate the complex flow characteristics near the cohesive banks, non-uniform cantilever failure and the longitudinal gradient of sediment transport. The proposed model should thus be improve in the future research.

\section{CONCLUSIONS}

The novel numerical modeling of the coupling fluvial erosion and cantilever failure was developed with the slump block effect. Two cases of cohesive materials with different silt-clay contents were considered under the similar hydraulic conditions.

The numerical modeling with slump block effects satisfactorily reproduced the fluvial erosion, cantilever failure and bank protection by the slump blocks. Additionally, the numerical results showed good agreement with the experimental results in terms of the spatial-averaged bank width. On the other hand, the numerical results without slump block effects showed the excessive fluvial erosion rate more than the experimental results. Therefore, the effect of the bank protection due to the slump block were clearly demonstrated in this study. Finally, we can conclude that the present numerical model is a powerful tool to analyze and predict the complex mechanism of a cantilever failure with slump blocks.

ACKNOWLEDGMENT: The authors would like to express their sincere thanks to the Japanese Government Scholarships for financial support.

\section{REFERENCES}

1) Dulal, K.P. and Shimizu, Y.: Experimental simulation of meandering in clay mixed sediments, J. Hydro-environ. Res., Vol.4(4), pp.329-343, 2010.

2) ASCE Task Committee on Hydraulics, Bank Mechanics, and Modelling Adjustment: River width adjustment. I: processes

and mechanisms, J. Hydraul. Eng., Vol.124(9), pp.881-902, 1998.

3) Duan J.G.: Analytical approach to calculate rate of bank erosion, J. Hydraul. Eng., Vol.131(11), pp.980-990, 2005.

4) Thorne, C.R. and Tovey, N.K.: Stability of composite river banks, Earth Surf. Proc. Land., Vol.6(5), pp.469-484, 1981.

5) Abam, T.K.S.: Genesis of channel bank overhangs in the Niger Delta and analysis of mechanisms of failure, Geomorphology, Vol.18(2), pp.151-164, 1997.

6) Dulal, K.P., Kobayashi, K., Shimizu, Y., and Parker, G.: Numerical computation of free meandering channels with the application of slump blocks on the outer bends, $J$. Hydro-environ. Res., Vol.3(4), pp.239-246, 2010.

7) Parker, G., Shimizu, Y., Wilkerson, G.V., et al.: A new framework for modeling the migration of meandering rivers, Earth Surf. Proc. Land., Vol.36(1), pp.70-86, 2011.

8) Patsinghasanee, S., Kimura, I., and Shimizu, Y.: Experimental and numerical study on overhanging failure of river bank, Annual Journal of Hydraulic Engineering, JSCE, Vol.71, No.4, pp.I_127-I_132, 2015.

9) Darby, S.E., Rinaldi, M. and Dapporto, S.: Coupled simulations of fluvial erosion and mass wasting for cohesive river banks, J. Geophys. Res., Vol.112(3). F03022: DOI: 10.1029/2006JF000722, 2007.

10) Samadi, A., Amiri-Tokaldany, E., Davoudi, M.H. and Darby, S.E.: Identifying the effects of parameter uncertainty on the reliability of modeling the stability of overhanging, multi-layered, river banks, Geomorphology, Vol.134(3-4), pp.483-498, 2011.

11) Samadi, A., Amiri-Tokaldany, E., Davoudi, M.H. and Darby S.E.: Experimental and numerical investigation of the stability of overhanging riverbanks, Geomorphology, Vol.184, pp.1-19, 2013.

12) Julian, J.P. and Torres, R.: Hydraulic erosion of cohesive riverbanks, Geomorphology, Vol.76(1-2), pp.193-206, 2006.

13) Partheniades, E.: Erosion and deposition of cohesive soils, J. Hydraul. Div. Am. Soc. Civ. Eng., Vol.91, pp.105-139, 1965.

14) Thorne, C.R. and Abt, S.: Analysis of riverbank instability due to toe scour and lateral erosion, Earth Surf. Proc. Land., Vol.18(9), pp. 835-843, 1993.

(Received September 30, 2015) 